\title{
Thematic-Based Big Book Learning Media as a Facility of Visual Learning Styles for Students
}

\author{
*Ela Risnaini ${ }^{1}$, Zerri Rahman Hakim², M. Taufik ${ }^{3}$ \\ 1.23Program Studi Pendidikan Guru Sekolah dasar, Universitas Sultan Ageng Tirtayasa, Banten, Indonesia
}

\author{
A R T I C L E I N F O \\ Article history: \\ 1 Mei 2020 Received in \\ revised form \\ 11 Juni 2020 \\ Accepted 10 Juli 2020 \\ Available online 25 Agustus \\ 2020

Kata Kunci:
big book, tematik, gaya
belajar
Keywords:
big book, thematic, learning
style

\begin{abstract}
A B S T R A K
Masih rendahnya penggunaan media pembelajaran inovatif oleh guru pada jenjang sekolah dasar menjadi suatu permasalahan serius pada saat ini. Penelitian ini bertujuan untuk mengembangkan media big book berbasis tematik sebagai sarana gaya belajar visual peserta didik di kelas IV Sekolah Dasar. Penelitian ini dilakukan di Sekolah Dasar pada kelas IV sejumlah 20 siswa dengan rincian 10 siswa pada uji coba terbatas. Model ini terdiri dari 6 tahap yaitu analisis masalah, pengumpulan data, desain produk, validasi desain, revisi desain dan uji coba produk. Instrumen yang digunakan berupa lembar angket untuk validasi media oleh dosen dan guru serta lembar angket peserta didik. Berdasarkan analisis data dapat disimpulkan kualitas media big book yang dikembangkan termasuk kategori layak dengan persentase $80 \%$ dari ahli media, kategori sangat layak dengan persentase $88 \%$ dari 2 ahli materi, dan $93,33 \%$ dari ahli bahasa. Respon peserta didik terhadap
\end{abstract} media big book pada uji coba dengan 10 responden sebesar 85,4\% dengan kategori sangat baik. Maka dapat disimpulkan bahwa penggunaan media big book ini dikatakan layak karena mampu mengatasi permasalahan-permasalahan yang ada di Sekolah Dasar.

\section{A B S T R A C T}

This study aimed to develop a thematic-based big book media as a means of visual learning styles of students in grade IV Elementary Schools. This research was conducted in Elementary School in class IV several 20 students with details of 10 students in a limited trial. In the learning process still using conventional methods, the use of media is not optimal and there are no media that contains some learning material. This model consists of 6 stages, namely problem analysis, data collection, product design, design validation, design revision, and product trials. The instrument used was a questionnaire sheet for media validation by lecturers and teachers as well as student questionnaire sheets. Based on data analysis, it can be concluded that the quality of the developed big book media is in the proper category with a percentage of $80 \%$ of media experts, a very feasible category with a percentage of $88 \%$ from 2 material experts, and $93.33 \%$ of linguists. Student responses to the big book media in the trial with 10 respondents amounted to $85.4 \%$ with a very good category. This big book media is said to be appropriate because it can overcome the problems that exist in elementary schools. very feasible category with a percentage of $88 \%$ from 2 material experts, and $93.33 \%$ of linguists. Student responses to the big book media in the trial with 10 respondents amounted to $85.4 \%$ with a very good category. This big book media is said to be appropriate because it can overcome the problems that exist in elementary schools. very feasible category with a percentage of $88 \%$ from 2 material experts, and $93.33 \%$ of linguists. Student responses to the big book media in the trial with 10 respondents amounted to $85.4 \%$ with a very good category. This big book media is said to be appropriate because it can overcome the problems that exist in elementary schools.

Copyright () Universitas Pendidikan Ganesha. All rights reserved 


\section{Introduction}

Education plays an important role in the progress of the nation and state. Education is essentially a conscious and planned effort to create an atmosphere of learning and the learning process so that students actively develop their potential and character (Fatonia, 2020; Syaparudin, 2020). Therefore, to develop human resources (HR) in students, the government is actively making changes. The changes made are of course for the advancement of education in Indonesia. One of the things that are being done by the government is developing the 2013 curriculum as a learning guide, conducting training and workshops for educators, and trying to facilitate adequate facilities and infrastructure.

Efforts to renew and improve the quality of government education ensure the implementation of a new curriculum, namely the 2013 Curriculum, which is a refinement of the previous KTSP curriculum. Along with government assurance regarding curriculum development from KTSP to Curriculum 2013, it raises a new challenge for teachers. The concept of the 2013 curriculum requires teachers to implement integrative thematic-based learning (Wangid et al., 2014; Fitria. S. A \& Agustriana, 2017). In addition to improving the curriculum, the government also carries out training for teaching staff. One of the pieces of training carried out was regarding the use of innovative learning media. The role of learning media in the learning and teaching process is an integral part of the world of education. Learning media is anything that can be used to channel the sender's message to the recipient so that it can stimulate the thoughts, feelings, attention, and interests of students to learn (Tafonao, 2018; Zayyadi et al., 2017)

The use of learning media must be clear and precise with the teaching material because this can affect the level of understanding of students so that they do not feel confused when paying attention to the explanation from the teacher. Learning media is an important element in the learning process. Media can help teachers in the teaching process which can be used as a tool that can distribute information or messages to students. Media is an inseparable part of the teaching and learning process for the achievement of educational goals in general and learning objectives in schools in particular. implicitly states that learning media includes tools that are physically used to convey the content of teaching materials which include books, tape recorders, tapes, video cameras, films, slides (picture frames), photos, pictures, graphics, television and computers (Arsyad, 2011; Sundayana. R, 2013). In other words, media is a component that can stimulate students to be enthusiastic about learning.

The various types of learning media, when viewed from the type of media, are divided into audio, visual, and audiovisual media, whereas when viewed from their coverage the media is divided into media with broad and simultaneous coverage, media with limited coverage by space, and space and media for coverage. individual teaching, when viewed from the material for making the media divided into simple media. Several types of learning media can be used in the learning process, one of which is graphic media. Graphic media includes visual media because graphic media functions to channel messages from the source to the message recipient. The channel used concerns the sense of sight. The message conveyed is embodied in symbols of visual communication (Djamarah \& Zain, 2010; Suryani N, 2018; Arsyad, 2018; Hamadi, 2011).

Learning media has various types and forms according to the characteristics of the teaching material discussed. One of the innovative media that can be used by teachers is the big book learning media. The big book learning media is a storybook with special characteristics that are raised in both text and images so that it allows reading activities together between teachers and students. This book has special characteristics such as being colorful, having words that can be repeated, has a storyline that is easy to guess, and has a simple text pattern (Alini, 2017; Oktaviana \& Wuryandani. W, 2019)

The development of the big book media is based on problems that occur in elementary schools, that learning is still using conventional methods, where teacher learning is still dominant as the center of learning. Less optimal use of learning media and the absence of media containing some learning materials. The big book being developed is a thematic-based big book that contains several learning materials including Indonesian, Social Studies, and Civics subjects. Because at this time, learning in elementary schools currently uses the 2013 curriculum, which is thematic-based learning. The curriculum is usually distinguished between the curriculum as a plan and a functional curriculum. The written plan is a curriculum document, while the curriculum that is operated in the classroom is functional. In this case, the 2013 Curriculum is an integrated curriculum, which means a curriculum model that can integrate skill, themes, concepts, and topics within single disciplines, across several disciplines, and within across learners (Syaodih, 2009; Amri \& Loeloek, 2013).

In the 2013 curriculum, the objectives of social studies learning are (1) IPS is developed as an integrative social studies subject, not as educational disciplines, as applied-oriented education, development of thinking skills, learning abilities, curiosity, and the development of a caring and 
responsible attitude, (2) ) The learning content in Junior High School / Madrasah Tsanawiyah which is based on integrated concepts from various disciplines for educational purposes is the subject of Social Sciences (IPS), (3) In essence, IPS is developed as a subject in the form of integrated social studies. The content of IPS comes from history, economics, geography, and sociology, (4) The objectives of social studies education emphasize understanding of the nation, the spirit of nationality, patriotism, and community activities in the economic sector in the space or territory of the Unitary State of the Republic of Indonesia, (5) Social studies education using a trans-disciplinary approach in which the boundaries of the disciplines no longer appear firm and clear, because the concepts of disciplines are mixed and/or related to the problems encountered around them and (6) Social studies learning is integrated through the concept of space, the connection between rooms, and time (Rojuli, 2016; Afandi. R., 2013).

Meanwhile, the objectives of social studies education in elementary school Gunawan., (2011); Nurhasanah, (2016) are (1) Equipping children with social knowledge that is useful in their future lives in society, (2) Equipping students with the ability to identify, analyze and compile alternative solutions to social problems that occur in community life, (3) Equipping students with the ability to communicate with fellow citizens of society and various scientific fields and fields of expertise, (4) Equipping students with awareness, positive mental attitudes and skills in environmental use life that is part of life, (5) Equipping students with the ability to develop social science knowledge and science following the development of life, society, science, and technology.

Thematic learning is one of the integrated learning models (integrated learning) at the kindergarten (TK / RA) or elementary school (SD / MI) for the original classes (i.e. grades 1, 2, and 3) which are based on themes (Rusman, 2010; Prastowo, 2019). Thematic learning is very important to be implemented in elementary schools because it has benefits. The benefits of thematic learning in elementary schools are (1) By combining some basic competencies and indicators and subject content there will be savings, because of that overlapping material can be reduced or even eliminated, (2) Students can see meaningful relationships because the content or learning material acts more as a means or tool, not a goal Finally, (3) Learning is not fragmented because students are equipped with a more integrated learning experience so that they will gain understanding with more integrated as well, (4) Providing applications from the real world, to increase the opportunity for transfer of learning, and (5) With the integration between subjects, the mastery of learning materials will be better and increase). Meanwhile, (Majid, 2014) states that thematic learning is integrated learning that uses themes to link several subjects so that they can provide meaningful experiences to students.

Reading together using the big book, students can be seen in the process of reading it. With its large size accompanied by attractive images, the big book has several characteristics that are an advantage for big book media. (Sepiani. S., \& Kurnia, 2017; Fazilla, 2016) the advantages of big book media are (1) Big books provide opportunities for children to be involved in real situations in ways that are not scary, (2) Big books allow all children to see writing when the teacher reads the writing, (3) The use of the big book allows the children together and cooperates the meaning of the writing in it, (4) The big book provides opportunities for children who are slow to read to recognize writing with the help of teachers and other friends, (5) The big book is liked by all children including those who are slow in reading because reading together will create courage and confidence in the children that they "can read".

This research is supported by several relevant studies, namely the results of research conducted by (Sundari, 2017) entitled "The Influence of Big Book Media on Early Childhood Speaking Ability" that the influence of big book media on children's speaking ability is due to the implementation of big book media. systematically by carrying out certain stages that have been designed to develop children's speaking abilities. In the experimental group that was treated using big book media, the average linguistic aspect of the child was 6.7 which was in the good category, and in the non-linguistic aspect of the child was 6.9 which was in the good category. Whereas in the control group that was not given treatment, the average aspect of children's language was 6.3 which was in the good category. The average non-linguistic aspect of the child is 6.5 which is in the good category. Furthermore, it is supported by research by (Mahsun \& Koriyah, 2019) which states that learning early reading skills leads to a significant increase based on student activeness and enthusiasm during learning. So that this can be increased by using the big book media maximally. This is evidenced by the average value of students' initial reading skills after the activity increased to 93.3\%. Then it is supported by research conducted by Marzoan, (2019) which states that Big Book media can improve students' reading skills.

Based on the information obtained, the objectives of this study are (1) To develop thematic-based big book learning media as a means of students 'visual learning styles, (2) To obtain the feasibility of thematic-based big book learning media as a means of students' visual learning styles and (3) To obtain the results of student responses to thematic-based big book learning media as a means of students' visual learning styles. 


\section{Method}

This study used to research and development methods (Research and Development). As the name implies, the research and development method are a method used to develop a particular product. This is in accordance with the opinion of Sugiyono, (2013) who states that development research is research that is used to produce a certain product and test the effectiveness of certain products. In line with the opinion of Sukmadinata, (2013) research and development is a process or steps to develop a new product or improve an existing product, which can be justified. Seeing time and cost limitations, this research leads to a modified (Sugiyono, 2011) design which includes six steps, namely problem analysis, data collection, product design, design validation, design revision, and product testing. Here are the steps in steps.

First Problem Analysis. The field study that researchers conducted was to analyze the curriculum first. The curriculum used in elementary schools is Curriculum 2013. In this curriculum analysis, researchers identify and understand Core Competencies (KI) and Basic Competencies (KD) through teacher books that are in accordance with the problems that researchers get. Furthermore, for material analysis, the researcher conducted an analysis of KI and KD in the book Theme 8 Sub-theme 1 and Learning-3. Researchers analyzed the material as well as analyzed the need to find the right solution to the learning material. After the researcher analyzed, the researcher took the 3rd learning material because this material requires the development of learning media that can attract the attention of students. Second Data Collection. The data collected at this stage were literature studies from curriculum analysis data, material analysis, and analysis of teaching and learning activities Theme 8 Sub-theme 1 Learning 3 using unstructured interviews. Third Product Design. The product development that would be produced in this research was in the form of print media, namely the big book. This big book would be designed according to the material contained in the book. Making product designs must pay attention to the suitability of the media with the learning objectives, the suitability of the media with the characteristics of students, it can be a source of learning, the efficiency, and effectiveness of media use, the ability of the media to develop the activeness and creativity of students, the ability of the media to develop a pleasant learning atmosphere, safety for learning, the quality of the media so that the design of this product is attractive and makes it easier for students to learn thematically.

Fourth, Design Validation Before testing a product that has been developed, it must pass through the validation stage (expert testing) first. This is done to find out whether the product that has been developed has met the criteria or not. Expert testing for media validation is carried out in 3 categories, namely media experts, material experts, and linguists. Fifth Product Revision. At this stage, revisions and validation results from the expert team were carried out. This aims to improve the weaknesses, after passing the trial it will be able to identify the weaknesses in the development carried out. This revision is carried out by providing criticism and suggestions through a research instrument. Sixth Product Trial. The big book media that has been validated by a team of experts is then subjected to a limited trial. This limited trial was carried out at the research location and will be tested on students while the learning takes place. This trial was conducted to determine the feasibility of the big book media that has been made. In a limited trial, students were given a questionnaire sheet to determine the response of students' assessment of the big book media.

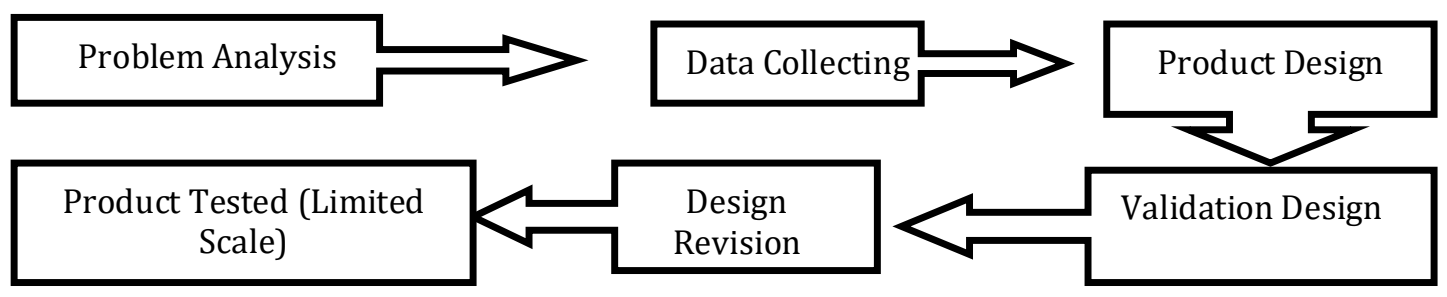

Figure 1. The flow of Modification of Research and Development (R\&D) Methods (Sugiyono, 2011)

The data collection technique used in this research was using interviews, questionnaires, and documentation.

\section{Interview Guidelines}


The interview used in this study was an unstructured interview that was used to interview fourthgrade elementary school teachers regarding the big book media needs analysis. An unstructured interview is a type of interview that only contains an outline that will be asked (Arikunto, 2006). Researchers used interview guidelines with the following blueprint

Table 1. Interview Guidelines Blueprint

\begin{tabular}{lcc}
\hline \multicolumn{1}{c}{ Aim } & Observed Aspects & Numbers of Item \\
\hline $\begin{array}{l}\text { To find out the needs of teachers } \\
\text { in the use of thematic-based big }\end{array}$ & learning styles of students Thematic learning & $1,2,3$ \\
$\begin{array}{l}\text { book learning media as a means of } \\
\text { visual }\end{array}$ & & $4,5,6,7,8$ \\
\hline
\end{tabular}

\section{Questionnaire}

Expert Judgement Questionnaire

Test of Media Experts

The media assessment sheet by expert testing is measured to measure the feasibility of the big book learning media. The following is the grid used to assess learning media, there is the table below.

Table 2. Media Expert Test Instrument Blueprint

\begin{tabular}{cllc}
\hline \multicolumn{1}{c}{ Aspects } & \multicolumn{1}{c}{ Indicators } & Number of Items & Total \\
\hline & A. Big Book Components & 1,2 & 2 \\
& B. Verbal & $3,4,5$ & 3 \\
Visual Communication & C. Cover Design & $6,7,8,9,10,11$ & 6 \\
& D. Content Design & $12,13,14$, & 3 \\
& E. Typography & $15,16,17,18,19$ & 5 \\
Media Engineering & F. Printing & $20,21,22$ & 3 \\
& Total & & 22 \\
\hline
\end{tabular}

Source: (Akbar, 2013)

\section{Material Expert Test Questionnaire}

This questionnaire is intended to determine and measure the feasibility of the learning media that researchers develop in terms of the learning materials presented in the big book learning media. The questionnaire grid for the material expert test is shown in table 3 below.

Table 3. Material Expert Test Instrument Blueprint

\begin{tabular}{|c|c|c|c|}
\hline Aspects & Indicators & Number of Items & Total \\
\hline \multirow{4}{*}{ Material } & A. Material Relevance. & $1,2,3,4,5$ & 5 \\
\hline & B. Accuracy of Material. & $6,7,8,9,10$ & 5 \\
\hline & C. Material enhancement & 11,12 & 2 \\
\hline & D. Encourage curiosity. & $13,14,15,16,17,18$ & 6 \\
\hline
\end{tabular}

Source: Modifikasi (Depdiknas, 2008)

\section{Linguist Test Questionnaire}

This questionnaire aims to determine and measure the feasibility of learning media that researchers have developed in the form of big book media by linguists. The questionnaire grid for measuring it is shown in table 4 below.

Table 4. Linguist Test Instrument Blueprint

\begin{tabular}{cclcc}
\hline \multicolumn{1}{c}{ Aspects } & \multicolumn{1}{c}{ Indicators } & Number of Items & Total \\
\hline \multirow{2}{*}{ Language } & A. & Legibility. & $1,2,3$ & 3 \\
& B. & Clarity of Information. & $4,5,6$ & 3 \\
& C. & Conformity with the rules of & $7,8,9$ & 3 \\
& & Indonesian that is good and correct. & $10,11,12$ & 3
\end{tabular}




\begin{tabular}{|c|c|c|c|}
\hline Aspects & Indicators & Number of Items & Total \\
\hline & Total & & 12 \\
\hline
\end{tabular}

\section{Student Response Questionnaire}

Student response questionnaires are used to determine students' responses to the big book media. The questionnaire used is closed, namely a questionnaire presented in such a way that the respondent is asked to choose one appropriate answer (Riduwan, 2013: 72). The questionnaire grid for student responses is as follows:

Table 5. Student Response Questionnaire Blueprint of Big Book Media Development

\begin{tabular}{|c|c|c|c|}
\hline \multirow{2}{*}{ Assessment Aspects } & \multirow{2}{*}{ Indicator } & \multicolumn{2}{|c|}{ Declaration Number } \\
\hline & & Positive & Negative \\
\hline \multirow{3}{*}{ Display } & Media appeal & 1 & 7 \\
\hline & The beauty of the image & 4 & \\
\hline & The attractiveness of the story & 5 & \\
\hline \multirow[t]{2}{*}{ Interest } & Shows an interest in thematic learning & 2 & 8 \\
\hline & The material is easy to understand & 3 & 9 \\
\hline Benefits & Make it easier for students to understand & 6 & 10 \\
\hline
\end{tabular}

The assessment of the expert test results was carried out based on input data in the form of an assessment sheet using a Likert scale with scores of 1, 2, 3, 4, and 5. The questionnaire data processing was carried out using a Likert scale. According to Sugiyono (2015: 135), the Likert scale is used to measure the attitudes, opinions, and perceptions of a person or group of people about social phenomena. The answer for each instrument item that uses the Likert scale has a gradient from very positive to very negative. Each student is asked to answer the available statements with a choice of Strongly Agree (SS), Agree (S), Doubt (RG), Disagree (TS), and Strongly Disagree (STS). The positive statement is multiplied by the value $S S=5, S=4, R G=3, T S=2$ and $S T S=1$ and vice versa, the negative statement is $S T S=5, T S=4$, $R G=3, S=2$, and $S S=1$. Next, the following is the grid for the big book learning media expert assessment instrument.

Table 6. Media Expert Assessment Instrument Grid of Big Book Learning Media

\begin{tabular}{ccc}
\hline \multirow{2}{*}{ Aspects } & \begin{tabular}{c} 
Assessment \\
\cline { 2 - 3 }
\end{tabular} \\
\hline
\end{tabular}

A. Big Book Components

1. Images on the big book media are suitable for students.

2. Text on big book media is clear.

B. Verbal

1. Suitability of sentences with the characteristics of students.

2. Clarity of sentence structure.

C. Cover Design

1. Harmonious and consistent appearance of the layout elements on the front and back covers.

2. Showing a good center of the view.

3. The cover color looks harmonious and consistent.

4. Accuracy of drawings and illustrations.

5. The cover illustration describes the material contained in the big book media.

6. The letters used are attractive and easy to read.

D. Content Design

1. Pawns and proportional margins.

2. Placement of illustrated pictures as the background does not interfere with the title and text.

E. Typography

1. Letter clarity. 


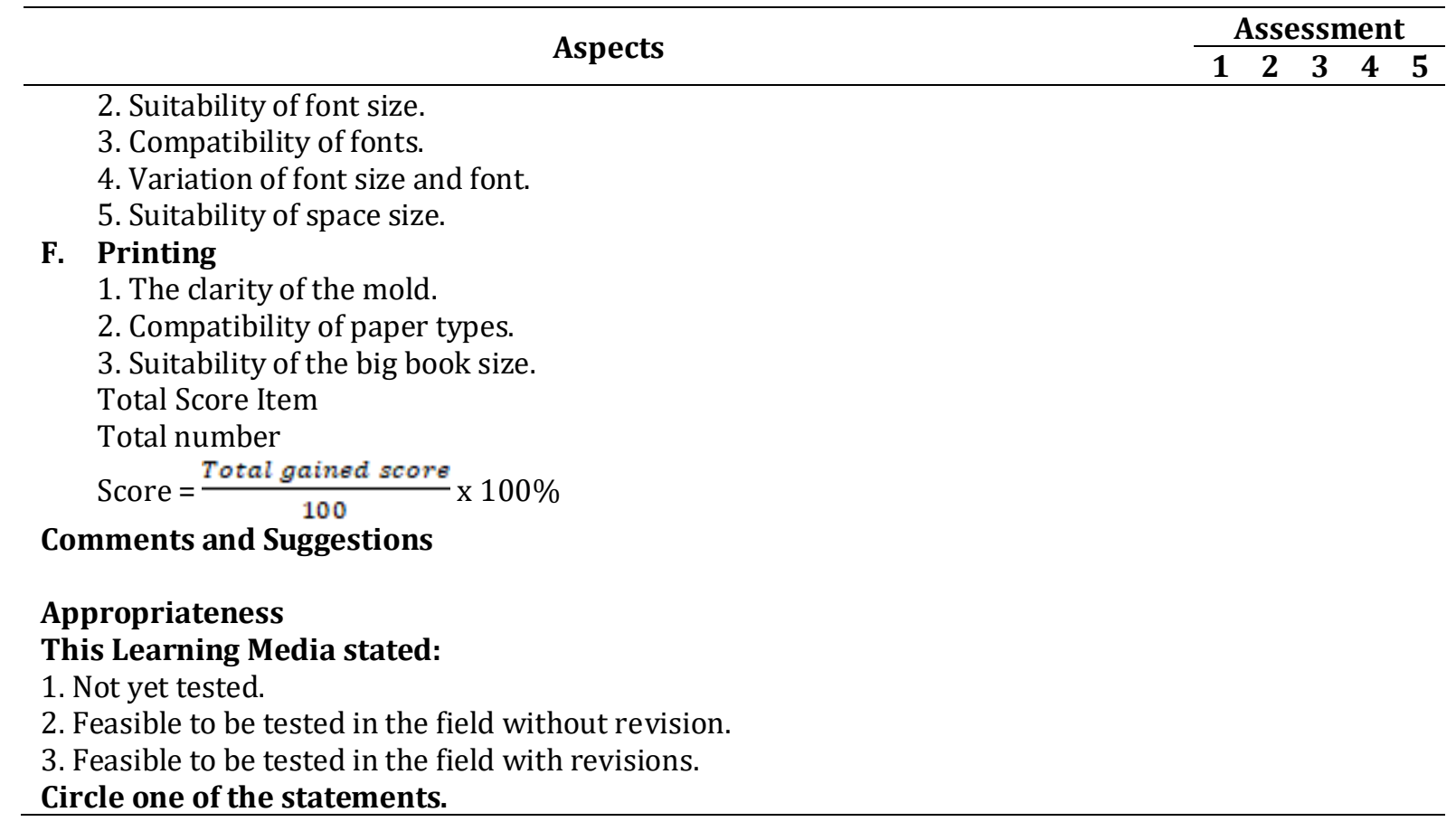

Table 7. Material Expert Assessment Instrument for Big Book Learning Media

\section{Aspects}

\section{A. Material Relevance}

1. Material on big book media is relevant to basic competencies

2. The material on the big book media is relevant to the indicators of competency achievement that must be mastered by students.

3. The depth of the material on the big book media is in accordance with the level of development of the characteristics of grade IV students.

4. The explanation in the big book media is relevant to the competencies that must be mastered.

5. Images on big book media are presented in accordance with the material.

\section{B. Material Accuracy}

1. The content of the material presented does not cause many interpretations.

2. The contents of the material are in accordance with everyday life.

3. The content of the material is presented efficiently to improve students' understanding.

4. Images and illustrations presented are in accordance with the real world.

C. Material Enhancement

1. The content of the material presented is in accordance with the development of students.

2. The relationship between pictures and illustrations with the material being taught in real-world situations.

\section{Encourages Curiosity}

1. Encourage the curiosity of students.

2. Creating the ability to ask questions.

3. Encourage students to build their knowledge.

4. Encourage students to learn in groups.

5. Encourage the interaction of students with learning resources.

Total Score of Items

Total

Score $=\frac{\text { Total of gained score }}{80} \times 100 \%$

Comments and suggestions

Appropriateness 


\begin{tabular}{lrr}
\hline \multicolumn{1}{c}{ Aspects } & Assessment \\
\cline { 2 - 3 } & $\mathbf{1} \mathbf{2} \mathbf{3} \mathbf{4}$ \\
\hline This Learning Media stated: & \\
1. Not yet tested. & \\
2. Feasible to be tested in the field without revision. & \\
3. Feasible to be tested in the field with revisions. & \\
Circle one of the statements. & \\
\hline
\end{tabular}

Table 8. Linguist Assessment Instrument for Big Book Learning Media

\begin{tabular}{llrrr}
\hline & \multirow{2}{*}{ Aspects } & \multicolumn{3}{c}{ Assessment } \\
\cline { 2 - 4 } & 1 & 2 & 3 & 4 \\
\hline
\end{tabular}
A. Readability
1. The sentence used represents the content of the material to be conveyed.
2. The sentences used are simple and clear.
3. The language used evokes a sense of interest to students

\section{B. Clarity of Information}

4. The sentence structure is in accordance with the students' understanding.

5. The message or information is conveyed in an interesting and common language

in written communication in Indonesian.

6. The language used is able to stimulate students

\section{Compliance with Indonesian rules}

7. The sentence used refers to the correct and correct Indonesian grammar rules.

8. The spelling used refers to improved guidelines.

9. The terms used are in accordance with the Big Indonesian Dictionary.

D. Use of language effectively and efficiently

10. Kesusuaian with the intellectual development of students.

11. Conformity with the emotional level of students

12. Consistency of use of terms.

Total item score

Total number

$$
\text { Score }=\frac{\text { Total of gained score }}{60} \times 100 \%
$$

\section{Comments and Suggestions}

\section{Appropriateness}

This Learning Media stated:

1. Not yet tested.

2. Feasible to be tested in the field without revision.

3. Feasible to be tested in the field with revisions.

Circle one of the statements.

Based on the questionnaires, it can be concluded that the results of expert validation assessments of thematic-based big book learning media are as follows. In the expert validator, the percentage is $80 \%$, the instrument is declared feasible. For material experts with a percentage of $88 \%$ the instrument is very feasible. The linguist validator percentage of the instrument $93 \%$ is very feasible. So that the average overall result is $87 \%$, therefore the instrument is very feasible. For more details, it is presented in table 9 .

Table 9. Expert Validation Results

\begin{tabular}{ccc}
\hline Validator & Percentage & Information \\
\hline Media Expert & $80 \%$ & Well worth it \\
Material Expert & $88 \%$ & Very Worth it \\
Linguist & $93 \%$ & Very Worth it \\
Average & $87 \%$ & Very Worth it \\
\hline
\end{tabular}


After the learning media was validated by various experts, then the media was tried out on students. The student response questionnaire grid is as follows:

Table 10. Student Response Questionnaire

\begin{tabular}{|c|c|c|c|c|c|}
\hline \multirow{2}{*}{ No } & \multirow{2}{*}{ Aspects } & \multicolumn{4}{|c|}{ Assessment } \\
\hline & & SS & S RG & TS & STS \\
\hline 1 & I am very happy to learn thematic using the big book. & & & & \\
\hline 2 & Media big book helps me to learn thematic. & & & & \\
\hline 3 & The material in the big book is easy for me to understand. & & & & \\
\hline 4 & The pictures and writing in the big book are very clear. & & & & \\
\hline 5 & Interesting material to read. & & & & \\
\hline 6 & I understand better learning using a big book. & & & & \\
\hline 7 & I feel bored learning to use the big book & & & & \\
\hline 8 & This big book makes it difficult for me to understand the learning material. & & & & \\
\hline 9 & Many words and sentences confuse me. & & & & \\
\hline 10. & The amount of reading made me bored. & & & & \\
\hline
\end{tabular}

\section{Result and Discussion}

Based on the need's analysis, it was carried out first with interviews with grade IV SD teachers related to the needs for using media in learning. Based on the interviews conducted, it was shown that the teacher had difficulties in learning. The density of teaching materials in the theme book makes students feel bored and bored during the learning process, this is due to the lack of use of learning media, especially in educational props.

The use of learning media at the elementary level has a very important role in the success of the teaching and learning process. The learning media used will help students capture the messages conveyed by the teacher regarding the teaching material being discussed. Limited use of media in thematic learning makes students and teachers confused. Because we all know that thematic learning is learning to integrate subjects. So, the teacher is very difficult to choose learning media to suit the teaching material. Due to the limitations of the learning media used, especially in thematic learning, it will affect the visual learning styles of students. The learning style of the students in question is seen by the teacher as being sleepy, quickly bored, cool alone, and easily tired.

The use of thematic-based big book media in learning will look more attractive because big book media is designed in color and has funny characteristics. The following is the production of the big book media.
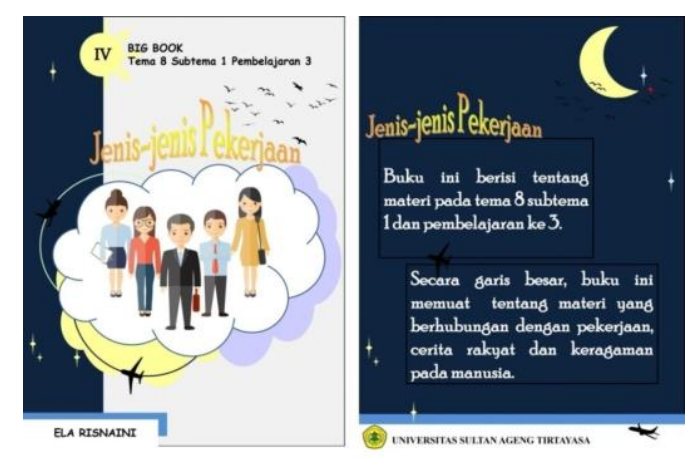

Figure 2. Front Cover and Back Cover

Based on the results of the big book learning media trial with 10 respondents, the following results can be obtained from the students' responses:

Table 13. Results of Student Response

\begin{tabular}{|c|c|c|c|c|c|c|c|c|c|c|c|c|c|}
\hline \multirow{2}{*}{ No } & \multicolumn{10}{|c|}{ Statements } & \multirow{2}{*}{ Score } & \multirow{2}{*}{ Percentage } & \multirow{2}{*}{ Information } \\
\hline & 1 & 2 & 3 & 4 & 5 & 6 & 7 & 8 & 9 & 10 & & & \\
\hline S1 & 5 & 4 & 3 & 4 & 4 & 3 & 4 & 5 & 4 & 4 & 40 & $80 \%$ & B \\
\hline $\mathrm{S} 2$ & 5 & 4 & 3 & 4 & 4 & 5 & 3 & 4 & 3 & 2 & 37 & $74 \%$ & B \\
\hline
\end{tabular}




\begin{tabular}{cccccccccccccc} 
S3 & 5 & 5 & 3 & 5 & 5 & 3 & 4 & 4 & 4 & 4 & 42 & $82 \%$ & SB \\
S4 & 5 & 4 & 3 & 5 & 5 & 4 & 5 & 2 & 4 & 3 & 40 & $80 \%$ & B \\
S5 & 5 & 4 & 5 & 5 & 5 & 5 & 4 & 4 & 4 & 4 & 45 & $90 \%$ & SB \\
S6 & 5 & 4 & 5 & 5 & 4 & 5 & 4 & 4 & 4 & 4 & 44 & $88 \%$ & SB \\
S7 & 5 & 4 & 4 & 4 & 4 & 4 & 5 & 4 & 5 & 4 & 43 & $86 \%$ & SB \\
S8 & 5 & 4 & 4 & 4 & 5 & 5 & 5 & 4 & 4 & 5 & 45 & $90 \%$ & SB \\
S9 & 5 & 4 & 5 & 5 & 5 & 4 & 4 & 3 & 4 & 4 & 43 & $86 \%$ & SB \\
S10 & 5 & 5 & 5 & 5 & 5 & 5 & 5 & 5 & 5 & 4 & 49 & $98 \%$ & SB \\
\hline Total & $\mathbf{5 0}$ & $\mathbf{4 7}$ & $\mathbf{4 5}$ & $\mathbf{4 6}$ & $\mathbf{4 6}$ & $\mathbf{4 3}$ & $\mathbf{4 3}$ & $\mathbf{3 9}$ & $\mathbf{4 1}$ & $\mathbf{3 6}$ & $\mathbf{4 2 8}$ & $\mathbf{8 5 , 4 \%}$ & SB \\
\hline
\end{tabular}

Based on the analysis of expert assessment data, the first percentage of media experts obtained results worth $80 \%$ in the "Eligible" category. This big book learning media is said to be feasible to develop because the big book components such as images on the media and the clarity of the big book media text are clear and can be understood by students, besides that the suitability of sentences with the characteristics of students is clear. Big book media is used in fourth-grade students of SD, so the language used must be simple and not convoluted so that it is easily understood by students. This will make students more active and eager to participate in learning. This is because this learning media is in accordance with its name, namely the big book is a book that is raised, so this big book has met the standard characteristics that must be owned, namely large and there are short stories in it to read. In line with the opinion Aini Dinda, (2017); Kriomi \& Faauziah, (2016); Anggraeni, (2016) that big book media has special characteristics such as being colorful, having words that can be repeated, having a storyline that is easy to guess and has a simple text pattern. thus, allowing the occurrence of reading activities together between teachers and students. So that the big book is not monotonous, the author also adds word cards that students can attach to certain sections as well as various page opening and closing techniques. the steps for making a big book, although pasting small pictures in the big book will look tidier, it is also fun to add design/design elements such as collages/paintings. In addition, the content of the material from the big book media already has the characteristics of thematic learning which presents several concepts from various learning content and several subjects are combined. This media reflects the real world around students and within the range of abilities and development of children (Akbar, 2016; Madyawati, 2017).

The two material experts scored 88\% in the "Very Appropriate" category. This media is said to be feasible because the clarity and relevance of the teaching material are clear. The material on the big book media is relevant to Basic Competencies and learning indicators. In addition, this media is said to be feasible because the content of the material presented does not cause many interpretations. The content of the material is in accordance with the daily life of students. Because applying innovative learning media such as the big book, students will automatically be fully involved in the learning process. Students become focused, interested in the contents of the big book, and interact with each other, both students and students, and students and teachers. Explained that the use of media that has a direct relationship with the environment around students will make students' understanding and memory stronger and longerterm(Kiromi \& Fauziah, 2018; Anggraeni, 2019). This is indicated by the students themselves finding their learning with friends assisted by the teacher. Students participate actively in learning activities. In addition, the relevance of teaching materials must be in accordance with basic competencies and indicators. It aims to limit the extent to which the teacher wants to achieve and measure the learning objectives. The big book media that is made is in accordance with the teaching material discussed with KD and the indicators to be achieved in accordance with the curriculum. The success of an innovative media is inseparable from its suitability to indicators and basic competencies of teaching materials (Setyaningsih \& Syamsudin, 2019; Syelvina \& Hariani, 2019).

The three linguists scored $93 \%$ in the "Very Appropriate" category. This media is said to be very feasible because the legibility of the sentences used represents the content of the material to be conveyed. In addition, the sentences used are still very simple, and clear, and the sentences used to refer to good and correct Indonesian grammar rules. The grammar used in big book media must be clear and easily understood by students(Setiani \& Kurniah, 2017; Elfiran et al., 2019). Long, wide and convoluted sentences will make students even more confused about the teaching material. So, the big book media must use simple and short sentences but refer to the material.

The fourth assessment of student response questionnaires obtained a percentage of $85.4 \%$ in the "Very Good" category. This media development is said to be very good because the response of students to the big book media is already above average. The big book media components such as the big book media display are very liked by students. The attractiveness of students towards the big book media is very high, 
the attractiveness of the images, the contents of the stories on the big book media are very high. Students become interested in learning using the big book media. Students feel happy and excited during learning, this is because the big book media has a very good appearance and is easy for students to understand. In addition, because in the 2013 curriculum, learning is carried out on a thematic basis, it will confuse students between learning science, social studies, Indonesian, and others on one theme. But by using the big book media, the teaching material is clear, the common thread between one lesson and another seems to be using stories and other funny pictures. This is what makes students excited and interested in learning. It can be concluded that thematic-based big book learning media as a means of visual learning styles of students meets the criteria as learning media. Other findings obtained through this research are developing a big book learning media.

The results of the research conducted by Dian Permatasari Kusuma Dayu and Liya Atika Anggrasari entitled "The Effect of Using Big Book Writing Media on Indonesian Language Writing Skills for 5th Grade Students of SD Negeri 1 Pilangbango Madiun" that the learning media Bigbook Writing obtained data on the results of writing skills of fifth-grade students. SDN Tegalarum in the control class or the untreated class using Big Book Writing learning media, only using conventional media has an average value of 67, while the experimental class or class treated using Big Book Writing learning media has an average value 73.5.

\section{Conclusions}

The feasibility of thematic-based big book learning media as a means of visual learning styles for students in grade IV elementary school was obtained through the validation of media experts, material experts, and linguists. The results of the development of thematic-based big book learning media as a means of visual learning styles for students are expected to be able to assist teachers in the learning process and can assist grade IV students in understanding thematic learning material on theme 8 subtheme 1 and learning 3. In addition, the big book media This thematic-based basis is expected to make innovation to develop further learning media.

\section{References}

Afandi, R. (2013). Integrasi pendidikan lingkungan hidup melalui pembelajaran IPS di sekolah dasar sebagai alternatif menciptakan sekolah hijau. PEDAGOGIA: Jurnal Pendidikan,2(1), 98-108. https://doi.org/10.21070/pedagogia.v2i1.50.

Aini Dinda, F. (2017). Penerapan Media Pembelajaran Big Book terhadap Kemampuan Pemahaman Konsep pada Mata Pelajaran Ilmu Pengetahuan Sosial. Serang: Tidak di Terbitkan.

Anggraeni, K. (2016). Efektivitas Metode Seinberg dengan Media Big Book terhadap Keterampilan Membaa Nyaring. Jurnal Cakrawala Pendas Universitas Majalengka. 2 (1). 83-94. http://dx.doi.org/10.31949/jcp.v2i1.322.

Akbar. (2013). Instrumen Perangkat Pembelajaran. Bandung: PT Remaja Rosdakarya.

Akbar, S dkk. (2016). Implementasi Pembelajaran Tematik di Sekolah Dasar. Bandung: PT Remaja Rosdakarya.

Amri, S. \& Loeloek, E. P. (2013). Panduan Memahami Kurikulum 2013. Jakarta: PT Prestasi Pustakarya.

Arikunto, S. (2006). Penelitian Suatu Pendekatan Praktik. Jakarta: Rineke Cipta.

Arsyad, A. (2011). Media Pembelajaran. Jakarta: PT Raja Grafindo Persada.

Dayu, D dan Liya. (2017). Pengaruh Penggunaan Media Big Book Writing Terhadap Keterampilan Menulis Bahasa Indonesia Siswa Kelas 5 SD Negeri 1 Pilangbango Madiun. Jurnal Pendidikan Dasar Islam. 9(1). 30. https://doi.org/10.14421/al-bidayah.v9i1.114.

Depdiknas. (2008). Panduan Pengembangan Bahan Ajar. Jakarta: Direktorat Jendral Manajemen Pendidikan Dasar dan Menengah.

Djamarah, S dan Zain. (2010). Strategi Belajar Mengajar. Jakarta: Rineka Cipta.

Elfiran, E., Munir, A., \& Hente, M. A. (2019). Meningkatkan Kemampuan Mengungkapkan Bahasa Melalui Metode Bercerita Menggunakan Media Big Book Di Kelompok B TK AL-MUTTAQIIN PALU. Jurnal Kolaboratif Sains, 1(1). https://doi.org/ 10.31934/jom.v1i1.665

Fatoni, A. (2020). Wawasan Pendidikan (Pendidikan dan Pendidik). Mida: Jurnal Pendidikan Dasar Islam, 3(1), 65-79. http://www.e-jurnal.unisda.ac.id/index.php/mida/article/view/1841 
Fazilla, S. (2016). Peningkatan Minat Belajar Mahasiswa dengan Menggunakan Media Pembelajaran Buku Besar (Big Book) pada Mata Kuliah Konsep Dasar Sains.Jurnal Pendidikan Dasar. 3 (1). 23-28. http://jfkip.umuslim.ac.id/index.php/jupendas/article/view/134.

Fitri, A., Saparahayuningsih, S., \& Agustriana, N. (2017). Perencanaan Pembelajaran Kurikulum 2013 Pendidikan Anak Usia Dini. Jurnal Ilmiah Potensia, 2(1), 1-13. https://doi.org/10.33369/jip.2.1.113.

Gunawan, R. (2011). Pendidikan IPS. Bandung: Alfabeta.

Hamdani. (2011). Dasar-dasar Pendidikan. Bandung: CV Pustaka Setia.

Hidayah, N. (2015). Pembelajaran Tematik Integratif di Sekolah Dasar. Terampil: Jurnal Pendidikan dan Pembelajaran Dasar, 2(1), 34-49. https://doi.org/10.24042/terampil.v2i1.1280.

Kiromi dan Fauziah. (2016). Pengembangan Media Pembelajaran Big Book untuk Pembentukan Karakter Anak Usia Dini. Jurnal Pendidikan dan Pemberdayaan Masyarakat Universitas Negeri Yogyakarta. 3 (1). 48-59. https://doi.org/10.21831/jppm.v3i1.5594.

Madyawati, L. (2017). Strategi Pengembangan Bahasa pada Anak. Jakarta: Kencana.

Mahsun, M., \& Koiriyah, M. (2019). Meningkatkan Keterampilan Membaca Melalui Media Big Book Pada Siswa Kelas Ia Mi Nurul Islam Kalibendo Pasirian Lumajang. Bidayatuna: Jurnal Pendidikan Guru Mandrasah Ibtidaiyah, 2(01), 60-78. https://doi.org/10.36835/bidayatuna.v2i1.361.

Majid, A. (2014). Pembelajaran Tematik Terpadu. Bandung: PT Remaja Rosdakarya.

Marzoan, M. (2019). Efektivitas Media Big Book Dalam Meningkatkan Keterampilan Membaca Permulaan Bagi Siswa Kelas Awal Di Sekolah Dasar. Realita: Jurnal Bimbingan dan Konseling, 3(6). http://ojs.ikipmataram.ac.id/index.php/realita/article/view/2136.

Nurhasanah, A. (2016). Penggunaan metode simulasi dalam pembelajaran Keterampilan Literasi Informasi IPS bagi Mahasiswa PGSD. JPsd Jurnal Pendidikan Sekolah Dasar),2(1), 87-95. http://dx.doi.org/10.30870/jpsd.v2i1.670

Oktaviana, N. F., \& Wuryandani, W. (2019). Pengembangan media big book untuk meningkatkan perilaku moral anak usia 5-6 tahun. JPPM (Jurnal Pendidikan dan Pemberdayaan Masyarakat), 6(1), 32-40. https://doi.org/10.21831/jppm.v6i1.23371

Oktavianti, R., \& Wiyanto, A. (2014). Pengembangan Media Gayanghetum (Gambar Wayang Hewan dan Tumbuhan) dalam Pembelajaran Tematik Terintegrasi Kelas IV SD. Mimbar Sekolah Dasar, 1(1), 6570. https://doi.org/10.17509/mimbar-sd.v1i1.865.

Prastowo, A. (2019). Analisis Pembelajaran Tematik Terpadu. Jakarta: Kencana.

Purwanto, N. (2013). Prinsip-Prinsip dan Teknik Evaluasi Pengajaran. Bandung: PT Remaja Rosdakarya.

Riduwan. (2009). Dasar-Dasar Statistika. Bandung: Alfabeta.

Riduwan. (2013). Belajar Mudah Penelitian Untuk Guru, Karyawan, dan Peneliti Pemula. Bandung: Alfabeta

Rojuli, S. (2016). Strategi Pembelajaran Pendidikan IPS. Surabaya: CV. Garuda Mas Sejahtera.

Rusman. (2010). Model-model Pembelajaran: Mengembangkan Profesionalisme Guru. Jakarta: Rajawali Pres.

Septiyani, S. (2017). Pengaruh Media Big Book terhadap Kemampuan Berbicara pada Anak Usia Dini. Jurnal Potensia. 2(1). 53. https://doi.org/10.33369/jip.2.1.47-56.

Septiyani, S., \& Kurniah, N. (2017). Pengaruh Media Big Book Terhadap Kemampuan Berbicara Pada Anak Usia Dini. Jurnal Ilmiah Potensia, 2(1), 47-56. https://doi.org/10.33369/jip.2.1.47-56.

Setiyaningsih, G., \& Syamsudin, A. (2019). Pengembangan Media Big Book Untuk Meningkatkan Kemampuan Literasi Anak Usia 5-6 Tahun. Scholaria: Jurnal Pendidikan Dan Kebudayaan, 9(1), 1928. https://doi.org/10.24246/j.js.2019.v9.i1.p19-28.

Sugiyono. (2011). Metode Penelitian Kuantitatif, Kualitatif dan R\&D. Bandung: Alfabeta.

Sugiyono. (2013). Metode Penelitian Kuantitatif, Kualitatifdan R\&D. Bandung: Alfabeta. 
Sugiyono. (2015). Metode Penelitian Pendidikan. Bandung: Alfabeta.

Sukmadinata, N.S. (2011). Metode Penelitian Pendidikan. Bandung: Remaja Rosdakarya.

Sundayana, R. (2013). Media Pembelajaran Matematika. Bandung: Penerbit Alfabeta.

Suryani, N dkk. (2018). Media Pembelajaran Inovatif dan Pengembangannya. Bandung: PT Remaja Rosdakarya.

Syafrudin, N dan Adrianto. (2016). Kurikulum dan Pembelajaran. Jakarta: PT Raja Grafindo.

Syaparuddin, S. (2020). Peranan Pendidikan Nonformal Dan Sarana Pendidikan Moral. JURNAL EDUKASI NONFORMAL, 1(1), 173-186. https://ummaspul.e-journal.id/JENFOL/article/view/317.

Syaodih, N. (2009). Pengembangan Kurikulum. Bandung: PT Remaja Rosdakarya.

Tafonao, T. (2018). Peranan media pembelajaran dalam meningkatkan minat belajar mahasiswa. Jurnal Komunikasi Pendidikan, 2(2), 103-11. https://doi.org/10.32585/jkp.v2i2.113

Trianto. (2014). Mendesain Model Pembelajaran Inovatif, Progresif, dan Kontekstual. Jakarta: Kencana Prenada Media Media Grup.

Wangid, M. N., Mustadi, A., Erviana, V. Y., \& Arifin, S. (2014). Kesiapan guru SD dalam pelaksanaan pembelajaran tematik-integratif pada kurikulum 2013 di DIY. Jurnal Prima Edukasia, 2(2), 175-182. https://doi.org/10.21831/jpe.v2i2.2717.

Zayyadi, M., Supardi, L., \& Misriyana, S. (2017). Pemanfaatan Teknologi Komputer Sebagai Media Pembelajaran Pada Guru Matematika.Jurnal Pengabdian Masyarakat Borneo,1(2), 25-30. https://doi.org/10.35334/jpmb.v1i2.298. 